\title{
Efeito das Fontes de Amido e Nitrogênio de Diferentes Degradabilidades Ruminais. 1. Digestibilidades Parcial e Total ${ }^{1}$
}

\author{
Fábio Luiz Fregadolli², Lúcia Maria Zeoula ${ }^{*}$, Ivanor Nunes do Prado ${ }^{3}$, Antônio Ferriani Branco ${ }^{3^{*}}$, \\ Saul Ferreira Caldas Neto ${ }^{4}$, Marcos Paulo Kassies ${ }^{5}$, Augusto Ortega Dalponte ${ }^{5}$
}

\begin{abstract}
RESUMO - Avaliaram-se as digestibilidades parcial e total de rações combinando fontes de amido (AM) de alta (casca de mandioca desidratada) e baixa (milho) degradabilidade ruminal, com fontes de nitrogênio ( $\mathrm{N}$ ) de alta (levedura) e baixa (farelo de algodão + farinha de carne e ossos) degradabilidade ruminal, em arranjo fatorial 2x2. Foram utilizados quatro novilhos da raça Holandesa ( $334 \mathrm{~kg}$ ), portadores de cânula ruminal e duodenal, distribuídos em delineamento quadrado latino 4x4. O óxido crômico foi utilizado como indicador de fluxo de matéria seca. Houve interação das fontes de AM e N sobre o coeficiente de digestibilidade aparente (CDA) da proteína bruta (PB) e fibra em detergente neutro (FDN). As rações com milho e levedura e as com casca de mandioca e farelo de algodão + farinha de carne e ossos apresentaram maior CDA para PB do que as rações com milho e farelo de algodão + farinha de carne e osso e com as casca de mandioca e levedura. A ração com amido e $\mathrm{N}$ de alta degradabilidade ruminal (casca de mandioca e levedura) propiciou menor valor sobre o CDA da FDN do que as demais rações, que não diferiram entre si. A digestão ruminal da FDN foi maior quando a fonte de AM foi o milho, comparada àquela contendo casca de mandioca. A maior digestão do AM foi para as rações com casca de mandioca, comparada às rações com milho, em todos os segmentos do trato digestivo. Observaram-se valores negativos para a digestão ruminal da PB para as rações experimentais. A fonte de $\mathrm{N}$ influenciou a digestão ruminal e intestinal da energia bruta. A maior a digestão ruminal ocorreu nas rações com levedura e a maior digestão intestinal, nas rações com farelo de algodão + farinha de carne e ossos.
\end{abstract}

Palavras-chave: casca de mandioca desidratada, farelo de algodão, farinha de carne e ossos, levedura, milho, sincronização

\section{Effect of Starch and Nitrogen Sources of Different Ruminal Degradability. 1. Total and Partial Digestibility}

\begin{abstract}
Total and partial digestibility of diets combining the starch sources of high degradability (dried cassava hulls) and low degradability (corn), with nitrogen sources of high (yeast) and low (cottonseed meal and meat and bone meal) degradability, in a $2 \times 2$ factorial arrangement, were evaluated. Four Holstein steers $(334 \mathrm{~kg}$ ) fitted with ruminal and duodenal cannulas, in a 4 x 4 Latin Square were used. Chromic oxide was used as a marker for drying matter flow. Interactions of starch and N sources on apparent digestibility coefficient (ADC) of crude protein (CP) and neutral detergent fiber (NDF) was detected. Diets of corn and yeast, cassava hulls and cottonseed meal + meat and bone meal showed higher ADC of CP than diets of corn and meat and bone meal and with cassava hulls and yeast. The diet of starch and $\mathrm{N}$ with high ruminal degradability showed lower value than others diets, that was not different. Ruminal digestion of NDF was higher when starch source was corn compared with cassava hulls. The highest digestion of starch was higher in diets with cassava hulls than in diets of corn, in all segments of digestive system. Negative values for ruminal digestion of CP to experimental diets were observed. The $\mathrm{N}$ source influenced ruminal and intestinal digestion of energy. The ruminal digestion was higher in diets with yeast e intestinal digestion was higher in diets with cottonseed meal + meat and bone meal.
\end{abstract}

Key Words: cassava hulls dried, corn, cottonseed meal, meat and bone meal, synchronisation, yeast

\section{Introdução}

A fermentação ruminal é conseqüência da digestão da matéria orgânica, regida pela atividade microbiana, sendo estas funções dependentes do fornecimento de energia e proteína da ração em taxas e quantidades adequadas (STOKES et al., 1991). Todavia, a efici- ência de utilização de substratos pela população microbiana envolve forte interação das frações de carboidratos e nitrogênio das rações (OLDHAM, 1982; NOCEK e RUSSEL, 1988). A atividade dos microrganismos ruminais e a utilização da dieta são influenciadas pela degradabilidade e quantidade das fontes de carboidratos e nitrogênio que compõem a

\footnotetext{
1 Parte da dissertação de mestrado do primeiro autor.

2 Aluno de mestrado PPG/UEM. E.mail: fabiolf@fcav.unesp.br

3 ProfessordoProgramadePós-graduação daUniversidade Estadual deMaringá;Av.Colombo,5790CEP8702-900-Maringá,PR.E.mail:Imzeoula@uem.br

4 Aluno de doutorado - PPG/UEM.

5 Bolsista de iniciação científica - CNPq.

* Bolsista Pesquisador - CNPq.
} 
dieta dos animais ruminantes (NATIONAL RESEARCH COUNCIL - NRC, 1985; ROONEY e PFLUGFELDER, 1986).

A deficiência ou a ineficiência da utilização da proteína dietética pode reduzir a digestão de carboidratos, no entanto, o nitrogênio é perdido na forma de amônia, quando a quantidade de carboidrato é insuficiente para a utilização da proteína para síntese microbiana. Segundo CASPER et al. (1990), variando a fonte e a degradabilidade dos carboidratos não-estruturais nas rações, podem-se maximizar a síntese de proteína microbiana no rúmen e a eficiência de utilização de proteína não degradável no rúmen.

A fração potencialmente degradável e a taxa de degradação dos carboidratos e proteína dos alimentos apresentam ampla variação, alterando a proporção dos produtos formados na fermentação ruminal (NOCEK e RUSSEL, 1988). Segundo NOCEK e TAMINGA (1991) e SAUVANT et al. (1994), os glicídios de velocidade de degradação lenta teriam vantagem quando comparados aos glicídios de velocidade de degradação rápida, que perturbariam o ecossistema ruminal. Todavia, a sincronização entre os ritmos de degradação de nitrogênio e glicídios no rúmen é mais favorável ao desenvolvimento da flora microbiana e da utilização dos alimentos (HERRERASALDANA et al., 1990; NOCEK e TAMINGA, 1991; CAMERON et al., 1991; MATRAS et al. 1991, SINCLAIR et al., 1993; SINCLAIR et al., 1995).

Alguns subprodutos da agroindústria apresentam características para compor as rações de ruminantes, entre eles, a levedura e os subprodutos da indústria de farinha de mandioca, que se caracterizam como fontes de nitrogênio e amido de alta degradabilidade ruminal. A levedura apresenta, em sua composição química, características que a colocam como alternativa de fonte alimentar, principalmente protéica para ruminantes. De acordo com Rose e Harrison (1970), citados por MATTOS et al. (1984), o conteúdo de proteína é bastante variável, de 30 a $60 \%$, e sua fração nitrogenada contém, em média, 70 a $80 \%$ de aminoácidos, 8 a $12 \%$ em ácidos nucléicos e 6 a $8 \%$ em amônia. Os subprodutos da indústria farinheira possuem potencial e disponibilidade para serem utilizados como fonte energética alimentar, entre os quais se destaca a casca de mandioca, que após a desidratação apresenta composição química média de $89,7 \%$ de MS, 3,6\% de PB, 33,2\% de FDN e 58,3\% de amido (CALDAS NETO, 1999).

O objetivo do presente experimento foi avaliar o efeito da combinação de fontes de amido (AM) com baixa e alta degradabilidade ruminal, o milho e casca de mandioca desidratada, respectivamente, e fontes de proteína com baixa e alta degradabilidade ruminal, o farelo de algodão + farinha de carne e ossos e levedura, respectivamente, sobre a digestibilidade parcial e total dos nutrientes em ruminantes.

\section{Material e Métodos}

O experimento foi realizado na Fazenda Experimental de Iguatemi (FEI) e as análises, no Laboratório de Análise de Alimentos e Nutrição Animal, pertencentes à Universidade Estadual de Maringá (UEM), Paraná.

Foram utilizados quatro bovinos, machos, castrados, da raça Holandesa, portadores de cânulas no rúmen e no duodeno e peso vivo médio de $334 \mathrm{~kg}$ ( $\pm 32 \mathrm{~kg}$ ). Os animais foram mantidos em baias individuais, com $2 \times 5$ metros de área, com piso de concreto e metade desta área coberta com folhas de zinco. As baias são cercadas por tábuas de madeira e providas de comedouro e bebedouro de concreto.

Para compor as rações experimentais, foi utilizado a silagem de milho, como volumoso; como concentrados energéticos, o milho e a casca de mandioca desidratada, respectivamente, fontes de amido de baixa e alta degradabilidade ruminal; e como concentrado protéico, a farinha de carne e ossos + farelo de algodão e levedura, respectivamente, fontes de nitrogênio de baixa e alta degradabilidade ruminal. A composição química dos alimentos utilizados e a composição percentual das rações experimentais são mostradas nas Tabelas 1 e 2 , respectivamente.

Com a combinação das fontes de AM e $\mathrm{N}$ de alta e baixa degradabilidade ruminal no desenho experimental fatorial $2 \times 2$, formularam-se quatro concentrados: milho e farelo de algodão + farinha de carne e ossos; milho e levedura; casca de mandioca desidratada e farelo de algodão + farinha de carne e ossos; e casca de mandioca desidratada e levedura, cuja degradabilidade efetiva da matéria seca, da proteína e do amido das rações experimentais encontra-se descrita na Tabela 3. Consta também na Tabela 3 a composição química das rações experimentais.

Os animais receberam, diariamente, $50 \mathrm{~g}$ de sal mineral, adicionados à ração no momento da alimentação. O sal mineral originou-se da mistura de partes iguais de sal comum e suplemento mineral comercial, contendo na sua composição $13 \%$ de fósforo, $17 \%$ de 
Rev. bras. zootec.

cálcio, $1 \%$ de magnésio, $2,4 \%$ de enxofre, 500 ppm de ferro, 800 ppm de cobre, 500 ppm de manganês, 50 ppm de iodo e 300 ppm de cobalto.

A quantidade de ração fornecida aos animais foi restrita a $2 \%$ do peso vivo, dividida em duas refeições, às 8 e 16 h.

Cada período experimental durou 19 dias, sendo 15 dias para adaptação dos animais à ração e quatro dias para coleta de alimentos, fezes, digesta e sobras. Durante os quatro dias do período de coleta, foram amostradas três vezes ao dia cerca de $200 \mathrm{~mL}$ de digesta duodenal e $100 \mathrm{~g}$ de fezes, com intervalo de $8 \mathrm{~h}$ e incremento de $2 \mathrm{~h}$ entre dias consecutivos, em um total de 12 amostras por animal. Também foram amostradas, diariamente, a silagem e as eventuais sobras de ração, para formar amostras compostas

Tabela 1 - Composição química (\% na MS) dos ingredientes das rações

Table 1 - Chemical and percent composition (\% DM) of ingredient of diets

\begin{tabular}{|c|c|c|c|c|c|c|c|c|}
\hline $\begin{array}{l}\text { Ingredientes } \\
\text { Ingredients }\end{array}$ & $\begin{array}{l}\text { MS } \\
D M\end{array}$ & $\begin{array}{l}\text { MO } \\
O M\end{array}$ & $\begin{array}{l}\mathrm{PB} \\
C P\end{array}$ & $\begin{array}{l}\mathrm{MM} \\
A S H\end{array}$ & $\begin{array}{c}\mathrm{EMF}^{1}(\mathrm{Mcal} / \mathrm{kg}) \\
F M E\end{array}$ & $\begin{array}{l}\text { FDN } \\
N D F\end{array}$ & $\begin{array}{l}\text { Amido } \\
\text { Starch }\end{array}$ & $\begin{array}{c}\mathrm{PDR}^{2} \\
D I P\end{array}$ \\
\hline & & & & & $\begin{array}{l}\text { \% na MS } \\
\% \text { in } D M\end{array}$ & & & $\begin{array}{l}\% \mathrm{~PB} \\
\% C P\end{array}$ \\
\hline $\begin{array}{l}\text { Milho } \\
\text { Corn }\end{array}$ & 88,39 & 98,72 & 9,60 & 1,28 & 2,82 & 12,09 & 72,28 & 45,00 \\
\hline $\begin{array}{l}\text { Casca de mandioca } \\
\text { Cassava hulls }\end{array}$ & 88,68 & 96,00 & 3,37 & 4,00 & 2,59 & 28,63 & 58,10 & 50,00 \\
\hline $\begin{array}{l}\text { Levedura } \\
\text { Yeast }\end{array}$ & 94,78 & 96,68 & 40,28 & 3,32 & 2,88 & - & - & 80,00 \\
\hline $\begin{array}{l}\text { F.carne e ossos } \\
\text { Meat bone meal }\end{array}$ & 90,25 & 64,23 & 39,07 & 35,77 & 1,65 & - & - & 50,00 \\
\hline $\begin{array}{l}\text { F. algodão } \\
\text { Cottonseed meal }\end{array}$ & 89,63 & 95,97 & 31,44 & 4,03 & 2,07 & 51,15 & 0,88 & 60,00 \\
\hline $\begin{array}{l}\text { Sal mineral } \\
\text { Mineral salt }\end{array}$ & 98,71 & - & - & 83,07 & - & - & - & - \\
\hline $\begin{array}{l}\text { Silagem de milho } \\
\text { Corn silage }\end{array}$ & 29,20 & 95,61 & 4,34 & 5,65 & 1,72 & 55,87 & 20,7 & 70,00 \\
\hline
\end{tabular}

Tabela 2 - Composição percentual das rações experimentais

Table 2 - Percent composition of experimental diets

\begin{tabular}{|c|c|c|c|c|}
\hline \multirow{2}{*}{$\begin{array}{l}\text { Fonte de amido } \\
\text { Starch source } \\
\text { Fonte de proteína } \\
\text { Protein source }\end{array}$} & \multicolumn{2}{|c|}{$\begin{array}{l}\text { Milho } \\
\text { Corn }\end{array}$} & \multicolumn{2}{|c|}{$\begin{array}{c}\text { Casca de mandioca } \\
\text { Cassava hull }\end{array}$} \\
\hline & $\begin{array}{c}\text { F. algodão e } \\
\text { F. carne e ossos } \\
\text { Cottonseed meal and } \\
\text { meat and bone meal }\end{array}$ & $\begin{array}{l}\text { Levedura } \\
\text { Yeast }\end{array}$ & $\begin{array}{c}\text { F. algodão e } \\
\text { F. carne e ossos } \\
\text { Cottonseed meal and } \\
\text { meat and bone meal }\end{array}$ & $\begin{array}{l}\text { Levedura } \\
\text { Yeast }\end{array}$ \\
\hline $\begin{array}{l}\text { Silagem de milho } \\
\text { Corn silage }\end{array}$ & 50,00 & 50,00 & 50,00 & 50,00 \\
\hline $\begin{array}{l}\text { Milho } \\
\text { Corn }\end{array}$ & 24,04 & 33,65 & - & - \\
\hline $\begin{array}{l}\text { Casca de mandioca } \\
\text { Cassava hulls }\end{array}$ & - & - & 22,12 & 31,85 \\
\hline $\begin{array}{l}\text { Levedura } \\
\text { Yeast }\end{array}$ & - & 16,35 & - & 18,15 \\
\hline $\begin{array}{l}\text { F.carne e ossos } \\
\text { Meat bone meal }\end{array}$ & 5,00 & - & 5,00 & - \\
\hline $\begin{array}{l}\text { F. algodão } \\
\text { Cottonseed meal }\end{array}$ & 20,91 & - & 22,84 & - \\
\hline $\begin{array}{l}\text { Fosfato bicálcio } \\
\text { Dicalcium phosphate }\end{array}$ & 0,84 & 0,84 & 0,84 & 0,84 \\
\hline
\end{tabular}


FREGADOLLI et al.

Tabela 3 - Composição química e degradabilidade efetiva das rações experimentais

Table 3 - Chemical composition and effective degradability of experimental diets

\begin{tabular}{|c|c|c|c|c|}
\hline \multirow{2}{*}{$\begin{array}{l}\text { Fonte de amido } \\
\text { Starch source } \\
\text { Fonte de proteína } \\
\text { Protein source }\end{array}$} & \multicolumn{2}{|c|}{$\begin{array}{l}\text { Milho } \\
\text { Corn }\end{array}$} & \multicolumn{2}{|c|}{$\begin{array}{c}\text { Casca de mandioca } \\
\text { Cassava hull }\end{array}$} \\
\hline & $\begin{array}{c}\text { F. algodão e } \\
\text { F. carne e ossos } \\
\text { Cottonseed meal and } \\
\text { meat and bone meal }\end{array}$ & $\begin{array}{l}\text { Levedura } \\
\text { Yeast }\end{array}$ & $\begin{array}{c}\text { F. algodão e } \\
\text { F. carne e ossos } \\
\text { Cottonseed meal and } \\
\text { meat and bone meal }\end{array}$ & $\begin{array}{c}\text { Levedura } \\
\text { Yeast }\end{array}$ \\
\hline$\overline{M S}(D M)$ & 47,85 & 47,27 & 47,63 & $47,30 \%$ na $\mathrm{MS}$ \\
\hline $\mathrm{MO}(O M)$ & 94,72 & 96,79 & 94,12 & 95,76 \\
\hline $\mathrm{PB}(C P)$ & 13,36 & 12,69 & 12,38 & 10,88 \\
\hline $\mathrm{EM}(M E), \mathrm{Mcal} / \mathrm{kg}$ & 2,51 & 2,63 & 2,39 & 2,46 \\
\hline $\operatorname{EMF}(F M E), \mathrm{Mcal} / \mathrm{kg}$ & 2,03 & 2,37 & 1,98 & 2,19 \\
\hline MM (Ash) & 5,00 & 3,03 & 5,65 & 3,93 \\
\hline $\operatorname{FDN}(N D F)$ & 45,70 & 36,17 & 50,11 & 41,22 \\
\hline $\operatorname{FDA}(N D F)$ & 26,67 & 19,66 & 30,90 & 24,75 \\
\hline AM (Starch) & 26,70 & 35,79 & 22,17 & 30,30 \\
\hline $\operatorname{PDR}(D I P)$ & 7,15 & $\begin{array}{r}7,54 \\
\text { Degrada } \\
E f\end{array}$ & bility & 7,10 \\
\hline $\operatorname{MS}(D M)$ & 39,91 & 58,49 & 48,51 & 72,57 \\
\hline $\mathrm{PB}(C P)$ & 54,97 & 78,61 & 60,15 & 92,02 \\
\hline AM (Starch) & 36,19 & 30,06 & 82,17 & 78,69 \\
\hline
\end{tabular}

aValores obtidos em experimento de degradabilidade in situ (FREGADOLLI et al., 2000).

a Values obtained with in situ degradability experiment (FREGADOLLI et al., 2000).

por animal e por período. As amostras permaneceram sob refrigeração, até o processamento.

Após o período de coleta, as amostras de digesta duodenal, fezes e sobras foram secas em estufa a $55^{\circ} \mathrm{C}$ por 96 horas, moídas em peneira de $1 \mathrm{~mm}$, individualmente, e misturadas em quantidades iguais, com base no peso seco, para formar amostras compostas de fezes e digesta por animal e para cada ração.

Foi utilizado óxido crômico $\left(\mathrm{Cr}_{2} \mathrm{O}_{3}\right)$, como indicador externo, para estimar o fluxo diário de matéria seca no duodeno e nas fezes. O óxido crômico foi fornecido em duas doses diárias de $5 \mathrm{~g}$ cada, colocadas por intermédio da fístula, no rúmen durante todo o período experimental. Os cálculos para determinação do fluxo da digesta, excreção fecal e coeficiente de digestibilidade aparente e parcial da MS e demais nutrientes foram realizados segundo SILVA e LEÃO (1979).

O NDT das rações foi estimado segundo o NRC (1996), considerando que $1 \mathrm{~kg}$ de NDT é igual a 4,409 Mcal de energia digestível (ED). Os cálculos para determinação de energia metabolizável (EM), energia líquida de mantença (Elm) e energia líquida de ganho (Elg) foram realizados utilizando as equações propostas por Garrett (1980), citadas pelo NRC (1996).
Nas amostras dos alimentos, da digesta duodenal, das fezes e da sobras, foram analisados os teores de MS, MO, PB e fibra em detergente neutro (FDN), utilizando os métodos citados por SILVA (1990). Os teores de amido foram determinados pelo método de Poore et al. (1989), adaptado por PEREIRA e ROSSI (1995), para leitura da glicose com Kit ENZCOLOR.

O conteúdo de cromo nas amostras de fezes e de digesta duodenal foi determinado por espectrofotometria de absorção atômica, segundo descrito por KIMURA e MILLER (1957) e usado juntamente com a concentração de nutrientes para determinar o fluxo de nutrientes para o duodeno e nas fezes. As leituras foram obtidas reduzindo a quantidade de amostra recomendada na metodologia de $500 \mathrm{mg}$ para $200 \mathrm{mg}$, pois se apresentaram mais confiáveis.

O delineamento experimental usado foi o quadrado latino $4 \times 4$. Os dados foram submetidos à ANOVA, utilizando o programa SAEG - Sistema de Análise Estatística e Genética (UNIVERSIDADE FEDERAL DE VIÇOSA-UFV, 1997), e a diferença entre as médias dos tratamentos determinada pelo teste de Tukey, considerando o nível de $5 \%$ de significância. 


\section{Resultados e Discussão}

As ingestões de MS, MO, PB, FDN e AM, em função do PV e peso metabólico (PM), estão apresentadas na Tabela 4. O consumo de MS dos animais foi restrito a $2 \%$ do peso vivo (PV), para diminuir os efeitos da ingestão sobre os coeficientes de digestão, favorecendo a comparação entre os dados. O consumo médio de MS foi de $1,94 \%$ do PV ou $84,5 \mathrm{~g} / \mathrm{kg}^{0,75}$, ficando próximo ao preestabelecido de $2 \%$ do PV. O consumo médio de MO foi $1,8 \%$ do PV ou $79,7 \mathrm{~g} / \mathrm{kg}^{0,75}$.

Houve interação $(\mathrm{P}<0,01)$ das fontes de $\mathrm{AM}$ e $\mathrm{N}$ no consumo de $\mathrm{PB}$, expresso em relação ao $\mathrm{PV}$ e ao PM. A menor concentração de $\mathrm{PB}$ na ração com casca de mandioca e levedura (Tabela 4) refletiu no menor $(\mathrm{P}<0,05)$ consumo de $\mathrm{PB}$ para esta ração de $0,21 \%$ do PV e $9,26 \mathrm{~g} / \mathrm{kg}^{0,75}$ do que para as demais rações, que não diferiram entre si, com valor médio de $0,25 \%$ do $P V$ e $10,8 \mathrm{~g} / \mathrm{kg}^{0,75}$.

Houve maior $(\mathrm{P}<0,01)$ ingestão de $\mathrm{AM}$, quando os animais receberam as rações com milho, de $0,61 \%$ do $P V$ ou $26,6 \mathrm{~g} / \mathrm{kg}^{0,75}$, em comparação às rações com casca de mandioca desidratada de $0,50 \%$ do PV ou $21,7 \mathrm{~g} / \mathrm{kg}^{0,75}$. Referente às fontes de proteína, rações com levedura proporcionaram aos animais maior consumo $(\mathrm{P}<0,01)$ de $\mathrm{AM}$ de $0,50 \%$ do $\mathrm{PV}$ ou $22,0 \mathrm{~g} / \mathrm{kg}^{0,75}$ do que rações com farelo de algodão + farinha de carne e ossos de $0,6 \%$ do PV ou $26,3 \mathrm{~g} / \mathrm{kg}^{0,75}$. Como o consumo de MS foi semelhante, as diferenças no consumo dos nutrientes são devidas a diferenças na concentração dos mesmos nas rações experimentais.

Os coeficientes de digestibilidade aparente (CDA) da MS, MO, PB, FDN e AM encontram-se na Tabela 5. Não houve efeito das fontes de $\mathrm{AM}$ e $\mathrm{N}$ sobre os CDA da MS e MO, observando-se valores médios de 59,3 e $62,4 \%$, respectivamente. Os valores apresentados para CDA da MS, no presente trabalho, estão próximos aos observados por ZEOULA et al. (1998), que, ao alimentarem vacas Holandesas, com rações com fontes de AM de alta (triticale) e baixa (milho) degradabilidade ruminal, combinadas com fontes de nitrogênio de alta (farelo de soja) e baixa (farelo de algodão + farinha de carne e ossos) degradabilidade ruminal, também não observaram efeito da interação das fontes sobre o CDA da MS, em consumo voluntário.

O valor médio obtido para o CDA da MO está próximo ao encontrado por MEDRONI (1997), de $61,1 \%$, que também não observou interação e efeito das fontes de AM (milho e triticale) e N (farelo de soja e levedura) para o CDA da MO. Todavia,
MARTINS (1999), fornecendo as mesmas rações utilizadas no presente trabalho a novilhas mestiças confinadas em consumo voluntário, obteve valore para o CDA da MO superior para rações com casca de mandioca, de $66,6 \%$, similar para rações com levedura, de $62,4 \%$, e inferior para rações com milho, de $52,1 \%$ e com farelo de algodão + farinha de carne e ossos, de 56,3\%, quando comparado aos valores do presente trabalho.

Houve interação das fontes de AM e N sobre os CDA da $\mathrm{PB}$, porém não para as fontes sincronizadas, para alta ou baixa degradabilidade ruminal. O maior $(\mathrm{P}<0,05) \mathrm{CDA}$ da $\mathrm{PB}$ foi observado para as rações com milho, quando este foi combinado com levedura de $57,2 \%$, em relação a farelo de algodão + farinha de carne e ossos de 51,1\%. Quando se utilizou casca de mandioca como fonte de AM, foi observado o inverso, maior CDA da PB ocorreu quando a fonte de $\mathrm{N}$ foi o farelo de algodão + farinha de carne e ossos, de $56,9 \%$, em relação à levedura, de 52,2\%.

Pode-se sugerir que a levedura, por ser uma fonte de $\mathrm{N}$ de alta solubilidade no rúmen, propiciou $\mathrm{N}$ prontamente disponível aos microrganismos e, com o fornecimento da energia proveniente do milho, resultou em melhor coeficiente de digestibilidade aparente da proteína, em relação às fontes de $\mathrm{N}$ de baixa degradabilidade.

Quando se comparam as fontes de nitrogênio estudadas, combinadas com a casca de mandioca como fonte de amido, de alta degradabilidade ruminal, é possível que o menor teor de $\mathrm{N}$ para a ração casca de mandioca e levedura, comprovado pelo menor consumo de $\mathrm{PB}$ para esta ração, explique em parte a menor digestibilidade da $\mathrm{PB}$ para a ração casca de mandioca e levedura, em comparação à casca de mandioca e farelo de algodão + farinha de carne e ossos. A maior ingestão diária de $\mathrm{PB}$ diluiria o efeito do $\mathrm{N}$ endógeno, aumentando o CDA da PB para rações mais ricas em N (RODRIGUES et al., 1997).

Segundo HENNING et al. (1993), vários graus de sincronização são atingidos, utilizando diferentes alimentos. Assim, nos estudos de sincronização, pode haver confundimento dos efeitos dos tratamentos com os efeitos dos ingredientes, o conteúdo total dos ingredientes e a taxa de degradação dos ingredientes no rúmen, levando a interpretações equivocadas.

Não houve interação das fontes de AM e N para o CDA da FDN. No entanto, o CDA da FDN, de $29,5 \%$ para a ração com casca de mandioca e levedura, foi $27 \%$ menor do que para as rações com casca de mandioca e farelo de algodão + farinha de carne 
FREGADOLLI et al.

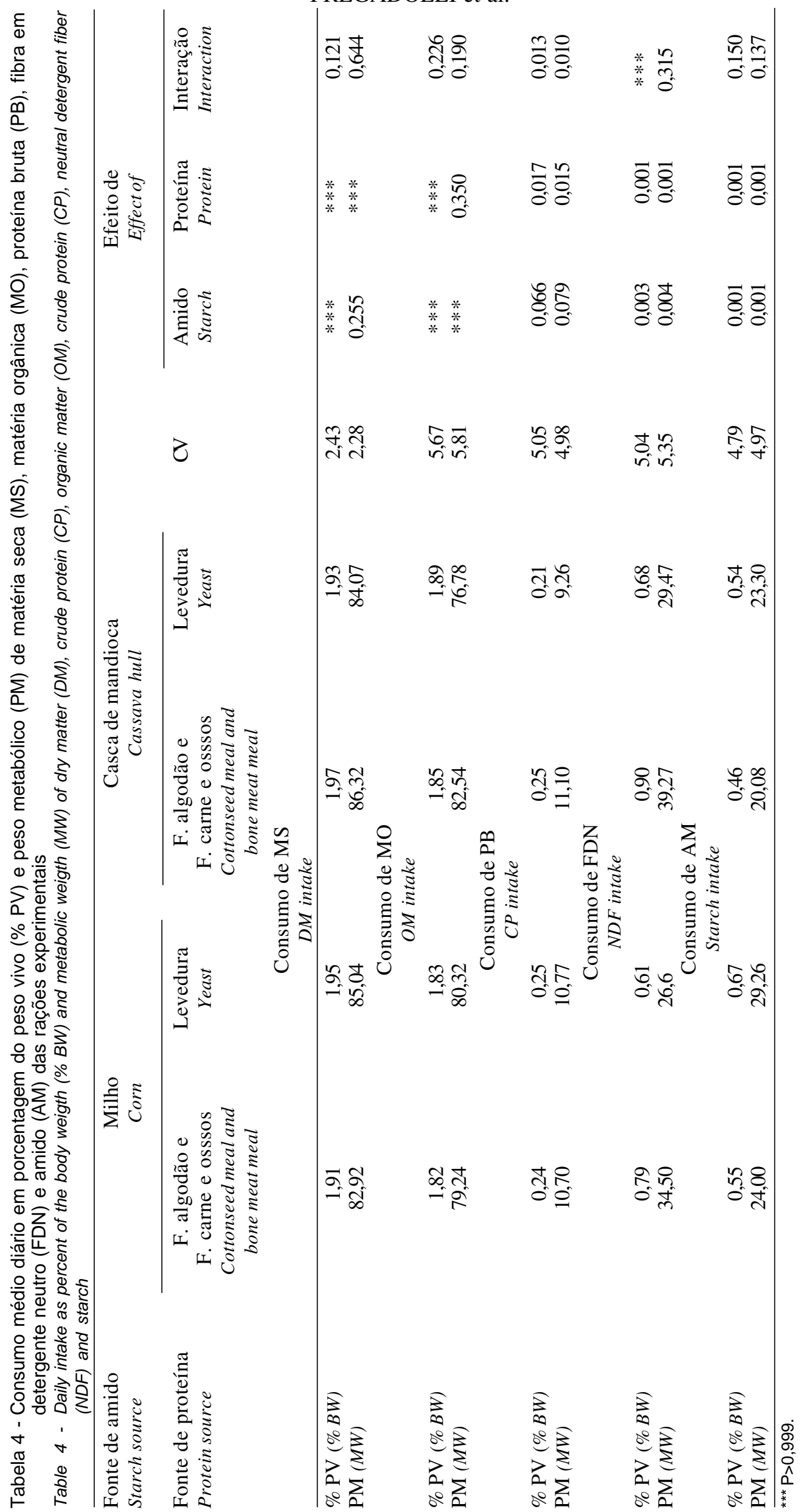


e ossos, milho e levedura, milho e farelo de algodão + farinha de carne e ossos, que apresentaram valor médio de 40,8\%. Redução nos CDA da FDN foram observados quando se adicionou uma fonte de AM mais fermentável (McCARTHY et al., 1989 e HOLZER et al., 1997) se elevou o conteúdo de amido na ração (CAMEROM et al., 1991). Esta redução pode ocorrer via diminuição no $\mathrm{pH}$ ruminal, devido à fermentação do AM excedente, produzindo ácido láctico (VAN SOEST, 1994). No presente experimento, as rações com levedura propiciaram maior consumo de AM do que as rações com farelo de algodão + farinha de carne e ossos e o pH ruminal dos animais alimentados com rações com levedura apresentou variação de 5,9 a 6,6 e média de 6,1 (FREGADOLLI, 2000). Segundo GRANT e MERTENS (1992), a inibição da atividade celulolítica das bactérias torna-se importante com $\mathrm{pH}$ abaixo de 6,2.

Houve efeito da fonte de amido $(\mathrm{P}<0,01)$ para o CDA do AM. Para rações com casca de mandioca, verificou-se maior $(\mathrm{P}<0,05) \mathrm{CDA}$ do $\mathrm{AM}$ de $96,2 \%$ do que para as rações com milho de $82,5 \%$.

O amido do milho, segundo WALDO (1973), fica protegido por um endosperma periférico, podendo dificultar a atividade microbiana. Provavelmente, foi o que ocorreu para o milho, visto que este foi moído em peneira grossa (mesh de $5 \mathrm{~mm}$ ) no presente experimento. Além disso, o amido do milho apresenta $76 \%$ de amilopectina e $24 \%$ de amilose, enquanto o amido da mandioca apresenta 83 e $17 \%$ de amilopectina e amilose, respectivamente (VILELA e FERREIRA, 1987). Segundo ROONEY e PFLUGFELDER (1986), a amilose se liga à cadeia cristalina da amilopectina, aumentando a quantidade de pontes de hidrogênio e diminuindo a hidrólise enzimática do amido. Também, a matriz protéica que envolve os grânulos de amido do milho diminuiria a digestibilidade ruminal.

As fontes de $\mathrm{N}$ não influenciaram o CDA do AM. Contudo, para o CDA do AM, observou-se superioridade de 7,5\% para as rações contendo farelo de algodão + farinha de carne e ossos, em comparação às rações com levedura, que concordam com as observações de Rust et al. (1979), citados por STREETER e MATHIS (1995). Segundo esses autores, o CDA do AM foi aumentado, quando a ingestão de $P B$ passou de deficiente para um nível mais adequado. No presente trabalho as rações contendo levedura propiciaram menor consumo de PB do que as rações com farelo de algodão + farinha de carne e ossos (Tabela 4), o que pode ter influenciado este resultado. 
Os valores obtidos no presente experimento concordam com o CDA do AM para as rações contendo casca de mandioca e foram maiores para as rações com milho, comparados aos resultados de MARTINS (1999) de 95,8 e 68,0\%, respectivamente. Esta diferença pode ser atribuída à provável variação na taxa de passagem, devido aos diferentes níveis de consumo entre os experimentos. No presente experimento, o consumo limitado pode ter diminuído a taxa de passagem, deixando os grãos de milho expostos por mais tempo à ação dos microrganismos ruminais. Tais valores foram similares aos observados para rações com milho e raspa de mandioca, em condições de consumo semelhantes ao do presente experimento (CALDAS NETO, 1999).

As digestões ruminal e intestinal da MS, MO, PB, FDN e AM estão apresentadas na Tabela 6. Não foi observado efeito da interação das fontes de $\mathrm{AM}$ e $\mathrm{N}$ para a digestão ruminal da MS, MO e PB. Observaramse valores médios para digestão ruminal da MS e MO de 54,1 e $63,9 \%$ do total digeridoe 32,2 e 39,9\% do ingerido, respectivamente, para as rações experimentais. Referente ao total digerido, o AGRICULTURAL RESEARCH COUNCIL - ARC (1984) considera que $65 \%$ da MO digestível é digerida no rúmen para diferentes rações.

Os baixos valores de digestão ruminal da MS e MO do presente trabalho podem ser atribuídos à variação na concentração de $\mathrm{N}-\mathrm{NH}_{3}$ no líquido ruminal, que apresentou valores entre 14,3 e 4,0 mg/ $100 \mathrm{~mL}$ (FREGADOLLI, 2000). Segundo ERDMAN et al. (1986), houve maior degradação ruminal da MS e do $\mathrm{N}$, quando a concentração de $\mathrm{N}-\mathrm{NH}_{3}$ foi de $25 \mathrm{mg} / 100 \mathrm{~mL}$ de líquido ruminal para rações com milho e $17 \mathrm{mg} / 100 \mathrm{~mL}$ de líquido ruminal para rações com farelo de algodão.

As rações formuladas visando à sincronização das fontes de AM e N, tanto para baixa quanto para alta degradação ruminal, apresentaram digestão ruminal da MO 10\% maior que as rações não sincronizadas. A degradabilidade efetiva da MS, para a taxa de passagem de $5 \% / \mathrm{h}$, também foi maior para a ração com fonte de $\mathrm{AM}$ e $\mathrm{N}$ de alta degradação ruminal e maior para ração com fonte de $\mathrm{N}$ de alta solubilidade (levedura), independente da fonte de amido.

Não houve efeito das fontes de AM e N sobre a digestão ruminal da $\mathrm{PB}$, apresentando valor médio de $-18,5 \%$ do ingerido. No entanto, a digestão ruminal da PB para a ração com milho e levedura foi $9,1 \%$ maior do que a ração com milho e farelo de algodão + farinha de carne e ossos, podendo esta diferença ser atribuída à menor degradabilidade ruminal do farelo de algodão + farinha de carne e ossos, comparada à levedura, e está de acordo com a degradabilidade efetiva da PB demonstrada na Tabela 3.

Os valores negativos para a digestibilidade ruminal da $\mathrm{PB}$ indicam que a quantidade de $\mathrm{N}$ chegando ao duodeno é maior que a ingerida, refletindo a reciclagem de $\mathrm{N}$ endógeno para o rúmen dos animais que consumiram as rações experimentais.

A digestão ruminal da FDN, expressa como porcentagem do total digerido, não diferiu $(\mathrm{P}>0,05)$ entre as rações experimentais e apresentaram valor médio de $88,8 \%$. CALDAS NETO (1999) também não observou diferença para a digestão ruminal da FDN, para rações com milho e derivados de mandioca de 93,5\% do total digerido. Com relação ao ingerido, as rações com milho apresentaram maior $(\mathrm{P}<0,05)$ digestão ruminal da FDN, de 39,3\%, do que as rações com casca de mandioca, de $25,9 \%$. $\mathrm{O}$ valor mínimo médio do $\mathrm{pH}$ do líquido ruminal para as rações com milho foi de 6,2 e para rações com casca de mandioca foi de 6,1 (FREGADOLLI, 2000), que poderia explicar estes resultados, estando em acordo com GRANT e MERTENS (1992), como já discutido anteriormente.

A digestão ruminal do AM, referente ao total digerido e ao ingerido, para rações com milho, de 72,6 e $59,7 \%$, foi menor $(\mathrm{P}<0,05)$ que para rações com casca de mandioca desidratada, de 91,6 e $88,2 \%$, semelhante aos resultados observados para o CDA do AM (Tabela 5). Estes resultados são confirmados pelos maiores valores de degradação ruminal do amido da mandioca, de $79,1 \%$, em relação ao milho, de 57,8\%, obtidos por ZEOULA et al. (1999), e da maior digestão ruminal e intestinal observada por CALDAS NETO (1999). De acordo com WALDO (1973), VILELA e FERREIRA (1987) e ROONEY e PFLUGFELDER (1986), as diferenças estruturais dos grânulos de amido presentes no milho e na mandioca seriam responsáveis pela menor e maior digestibilidade das fontes testadas, como discutido anteriormente.

Em relação ao total digerido, a fonte de $\mathrm{N}$ não apresentou efeito sobre a digestão ruminal do AM, apresentando valor médio de $82,1 \%$. Todavia, com relação ao ingerido, rações com farelo de algodão + farinha de carne e ossos proporcionaram maior $(\mathrm{P}<0,05)$ digestão ruminal do $\mathrm{AM}$, de $79,8 \%$, do que rações com levedura, de $68,2 \%$. De acordo com HUSSEIN et al. (1991), a fonte de N (farelo de soja ou farinha de peixe) influenciou a digestão 
ruminal do amido. STREETER e MATHIS (1995) observaram efeito quadrático da suplementação de farinha de peixe como fonte de $\mathrm{N}$, sobre a digestão ruminal do AM.

Houve interação das fontes de AM e $\mathrm{N}$ sobre a digestão intestinal somente para a FDN, com relação à quantidade que chegou ao duodeno. O maior valor para digestão intestinal da FDN, foi observado para a ração com casca de mandioca e farelo de algodão + farinha de carne e ossos, de $20,1 \%$ do que para as demais rações, que não diferiram entre si, valor médio de $2,1 \%$.

Houve efeito das fontes de AM sobre a digestão intestinal do AM (Tabela 6). A digestão intestinal do AM (\% do total digerido) foi maior $(\mathrm{P}<0,05)$ para rações com milho, de $27,3 \%$, comparada com casca de mandioca desidratada, de $8,3 \%$, como conseqüência da menor digestão ruminal do AM do milho. Todavia, quando a digestão intestinal do AM foi expressa em relação à quantidade que chegou ao duodeno, não houve diferença entre as fontes de $\mathrm{AM}$ e $\mathrm{N}$ e o valor médio obtido foi $61,3 \%$.

Segundo NOCEK e TAMMINGA (1991), há correlação positiva entre a quantidade de AM, que escapa da digestão ruminal e digestão intestinal. No entanto, apesar do maior fluxo de AM para o duodeno, de $10,7 \mathrm{~g} / \mathrm{kg}^{0,75}$, para as rações com milho, comparadas às rações com casca de mandioca, de $2,5 \mathrm{~g} / \mathrm{kg}^{0,75}$, a digestão intestinal do AM, para as rações com milho, de $56,0 \%$, foi $15 \%$ menor do que para as rações com casca de mandioca, de $66,5 \%$. As barreiras estruturais relatadas por ROONEY e PFLUGFELDER (1986) e a limitada digestão intestinal, observada por BRANCO (1998), quando níveis mais elevados de amido de $40 \mathrm{~g} / \mathrm{h}$ chegaram ao intestino, por meio da perfusão abomasal de AM em bovinos, poderiam estar refletindo nestes resultados.

O consumo, os coeficientes de digestibilidade aparente, a digestão ruminal e a digestão intestinal da energia bruta (EB) e os valores energéticos das rações experimentais podem ser observados na Tabela 7.

Houve interação das fontes de AM e N para consumo de energia bruta (CoEB). As rações com milho e farelo de algodão + farinha de carne e ossos tiveram menor CoEB do que as rações com milho e levedura, casca de mandioca e farelo de algodão + farinha de carne e ossos e casca de mandioca e levedura.

Não houve interação das fontes de $\mathrm{AM}$ e N, e das fontes de AM sobre o CDA, digestão ruminal, coeficiente de digestibilidade ruminal, coeficiente de digestibilidade intestinal e digestão intestinal da energia. Todavia, a digestão ruminal e intestinal (\% do total digerido) da EB foi influenciada pelas fontes de N. A fonte de alta degradabilidade ruminal, levedura propiciou maior $(\mathrm{P}<0,05)$ digestão ruminal da EB, de 63,3\%, em relação à de baixa degradabilidade, farelo de algodão + farinha de carne e ossos, de 50,4\%. Já a digestão intestinal de EB foi maior para a fonte de $\mathrm{N}$ de menor degradabilidade (farelo de algodão + farinha de carne e ossos) ou de maior escape ruminal.

Os valores de nutrientes digestíveis totais (NDT), energia digestível (ED), energia metabolizável (EM), energia líquida de mantença (ELm) e de ganho (ELg) foram obtidos a partir do CDA da energia bruta observado no presente experimento. Os valores estimados para ELm de 1,1 Mcal/kg e para ELg, de 0,6 Mcal/kg, das rações experimentais, foram inferiores às exigências energéticas para esta categoria animal, segundo o NRC (1988) que preconiza 1,6 Mcal/kg para ELm e 1,0 Mcal/kg para ELg.

\section{Conclusões}

As fontes de amido, de alta e baixa degradabilidade ruminal, em combinação com fontes de nitrogênio, de alta e baixa degradabilidade ruminal, interagiram-se somente para a digestibilidade no trato gastrintestinal da proteína bruta e da fibra em detergente neutro e na digestibilidade intestinal da fibra em detergente neutro. Os demais parâmetros analisados foram influenciados pela fonte de amido ou pela fonte de nitrogênio. A fonte de amido teve efeito sobre as digestibilidades aparente, ruminal e intestinal do amido e fonte de nitrogênio teve efeito na digestibilidade total e ruminal do amido e da energia bruta.

Os altos valores negativos para a digestão ruminal da proteína bruta refletiram em inadequado suprimento de nitrogênio e reciclagem de nitrogênio, sendo mais evidente para a ração com casca de mandioca e levedura do que para as rações com milho e farelo de algodão + farinha de carne e ossos, milho e levedura e casca de mandioca e farelo de algodão + farinha de carne e ossos. 
FREGADOLLI et al.

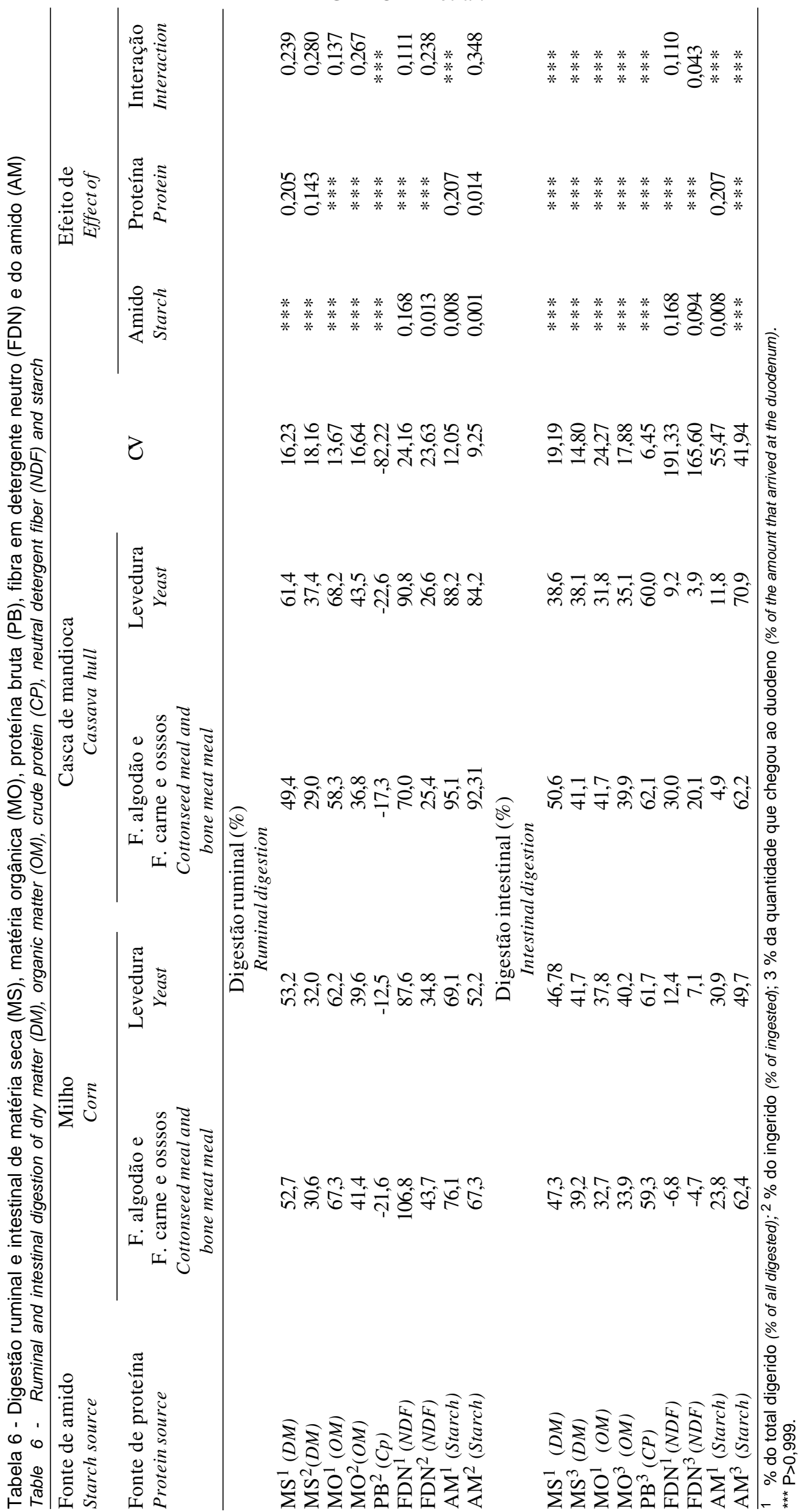




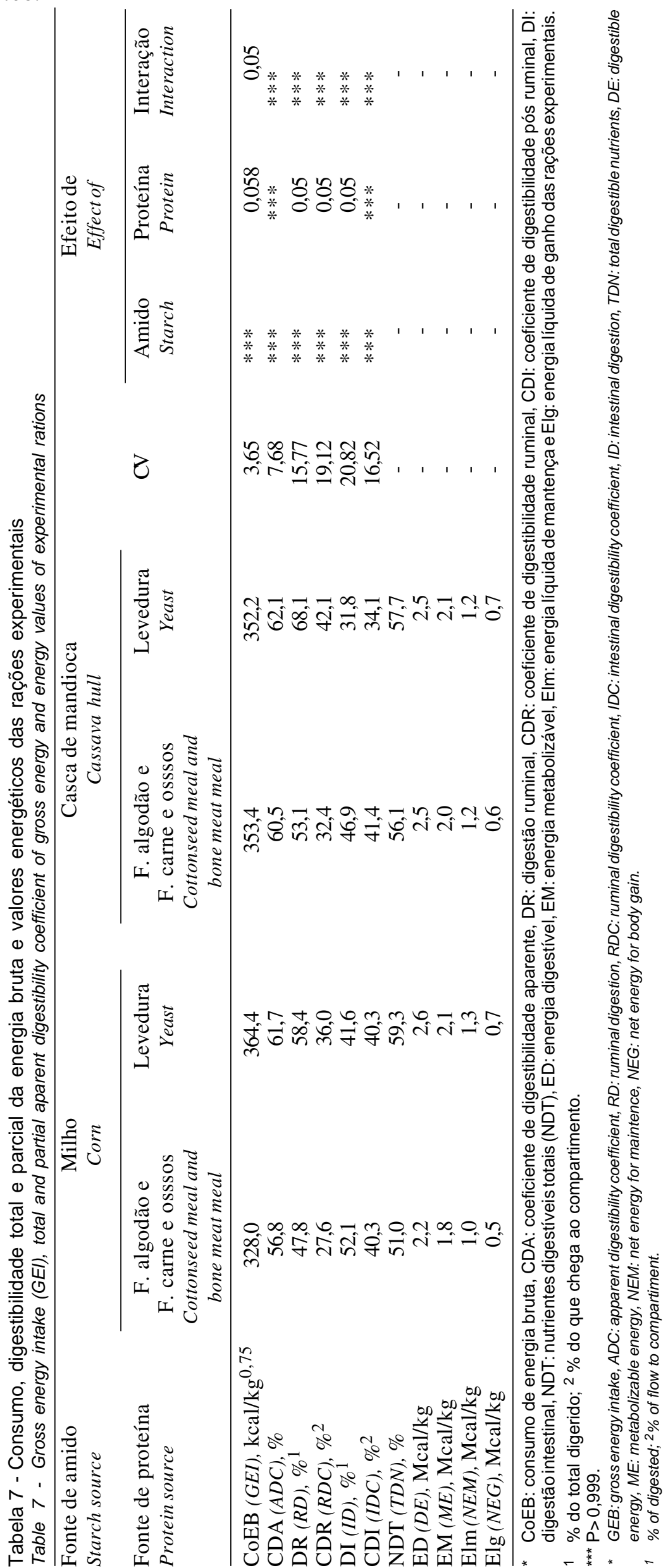




\section{Referências Bibliográficas}

AGRICULTURAL RESEARCHCOUNCIL - ARC. 1984. Report of the protein group of the Agricultural Research Council Working party, on the nutrient requeriment of ruminants. London: Commonwealth Agricultural Bureaux. 45p.

AGRICULTURAL AND FOOD RESEARCH COUNCIL AFRC. 1993. Technical committee on responses to nutrients: energy and protein requirements of ruminants. Wallinford: CAB INTERNATIONAL. 159p.

BRANCO, A.F. Digestão de amido no intestino delgado e grosso em bovinos e os feitos da disponibilidade abomasal de diferentes carboidratos sobre o fluxo portal-hepático de nutrientes em ovinos. Jaboticabal, SP: UNESP, 1998. 131p. Tese (Doutorado em Zootecnia) - Universidade Estadual Paulista, 1998.

CALDAS NETO, S.F. Digestibilidade parcial e total, parâmetros ruminais e degradabilidade de rações com mandioca $e$ resíduos das farinheiras. - Maringá, PR: UEM, 1999. 66p. Dissertação (Mestrado em Zootecnia) - Universidade Estadual de Maringá, 1999.

CAMERON, M.R., KLUSMEYER, T.H., LYNCH, G.L. et al. 1991. Effects of urea and starch on rumen fermentation nutrient passage to the duodenum and performance of cows. J. Dairy Sci., 74(4):1321-1336.

ERDMAN, R.A., PROCTOR, G.H., VANDERSALL, J.H. 1986. Effect of rumen ammonia concentration on in situ rate and extent of digestion of feedstuffs. J. Dairy Sci., 69:2313-2320.

FREGADOLLI, F.L., ZEOULA, L.M., DALPONTE, A.O. et al. Degradabilidade in situ de rações com diferentes fontes de amido e nitrogênio. In: REUNIÃO ANUAL DA SOCIEDADE BRASILEIRA DE ZOOTECNIA, 37, 2000, Viçosa. Anais... Viçosa: SBZ, 2000. p.287.

FREGADOLLI, F.L. Efeitos da degradabilidade ruminal do amido e do nitrogênio da dieta sobre o metabolismo ruminal e a digestibilidade em bovinos. Maringá, PR: UEM, 2000. 68p. Dissertação (Mestrado em Zootecnia) - Universidade de Estadual de Maringá, 2000.

GRANT, R.J., MERTENS, D.R. 1992. Influence of buffer pH and raw corn starch addition on in vitro fiber digestion kinetics. J. Dairy Sci., 75(8):2762-2768.

HENNING, P.H., STEYN, D.G., MEISSNER, H.H. 1993. Effect of syncronization of energy and nitrogen supply on ruminal chracteritics and microbial growth. J. Anim. Sci., 71(9):2516-2528.

HERRERA-SALDANA, R.E., GOMEZ-ALARCON, R., TORABI, M. et al. 1990. Influence of synchronizing protein and starch degradation in the rumen on nutrient utilization and microbial protein synthesis. J. Dairy Sci., 73(1):142-148.

HOLZER, Z., AHARONI, Y., LUBIMOV, V. et al. 1997.The feasibility of replacement of grain by tapioca in diets for growingfattening cattle. Anim. Feed Sci. Techn., 64(2):133-141.

HUSSEIN, H.S., JORDAN, R.M., STEM, M.D. 1991. Ruminal protein and intestinal amino acid utilization as affected by dietary protein and carbohydrate sources in sheep. J. Anim. Sci., 69(5):2134-2146.

KIMURA, F.T., MILLER, V.L. 1957. Improved determination of cromic oxide in calves feed and feces. J. Agric. Food Chem., $5(2): 216$.

MARTINS, A.S. Desempenho de novilhas alimentadas com rações contendo milho ou casca de mandioca e farelo de algodão ou levedura - Maringá, PR: UEM, 1989. 84p. Dissertação (Mestrado em Zootecnia) - Universidade Estadual de Maringá, 1999.

MATRAS, J., BARTLE, S.J., PRESTON R.L. 1991. Nitrogen utilization in growing lambs: effects of grain (starch) and protein sources with various rates of ruminal degradation.
J. Anim. Sci., 69(1):339-347.

McCARTHY, R.D., KLUZMEYER JR., T.H., CLARK, J. H., NELSON, D. R. 1989. Effects of source of protein and carbohidrate on ruminal fermentation and passage of nutrients to the small intestine of lactating cows. J. Dairy Sci., 72(8):2002-2016.

MEDRONI, S. Efeito da combinação de carboidratos e proteínas sobre a degradabilidade, digestibilidade e desempenho de novilhas Nelore confinadas. Maringá, PR: UEM, 1997.46p. Dissertação (Mestrado em Zootecnia) - Universidade Estadual de Maringá, 1997.

NATIONAL RESEARCH COUNCIL - NRC. 1988. Comittee on animal nutrition. Nutrient requirements of dairy cattle. 6.ed., Washington: National Academy of sciences. 157p.

NATIONAL RESEARCH COUNCIL - NRC. 1996. Nutrient requeriment of beef cattle. 7.ed. Washington D.C. National Academic Press. 242p.

NOCEK, J.E., TAMMINGA, S.1991. Site of digestion of starch in the gastrointestinal tract of of dairy cows and its effect om milk yield and composition. J. Dairy Sci., 74(10):3598-3629.

PEREIRA, J.R.A, ROSSI, P. Manual prático de avaliação nutricional de alimentos. Piracicaba: FEALQ, 1995. 25p.

POORE, M.H., ECK, T.P., SWINGLE, R.S., THEURER, C.B Total starch and relative starch avaliability of grains. In: BIENAL CONFERENCE ON RUMEN FUNCTION, 1989, Chicago. Abstracts...Chicago, 1989. v.20, p.35.

RODRIGUEZ, L.R.R., FONTES, C.A.A., JORGE, A.M. et al. 1997. Digestibilidade de rações contendo quatro níveis de concentrado em bovinos (taurinos e zebuínos) e bubalinos. R. Soc. Bras. Zootec., 26(4): 844-851.

ROONEY,L.W., PFLUGFELDER, R.L. 1986. Factors affecting starch digestibility with special emphasis on shorghum and corn. J. Anim. Sci., 63(5):1607-1623.

SILVA, D.J. 1990. Análise de alimentos - Métodos químicos e biológicos. 2 ed. Viçosa: UFV. 166p.

SILVA, J.F.C., LEÃO, M.I. 1979. Fundamentos de nutrição dos ruminantes. Piracicaba: Livroceres. 380p.

SINCLAIR. L.A., GARNSWORTHY, P.C., NEWBOLD, J.R., et al. 1993. Effects of synchronizing the rate of dietary energy and nitrogen release on rumen fermentation and microbial protein synthesis in sheep. J. Agric. Sci., 120:251-263.

SINCLAIR. L.A., GARNSWORTHY, P.C., NEWBOLD, J.R., et al. 1995. Effect of synchronizing the rate of dietary energy and nitrogen release in diets with a similar carboidrate composition on rumen fermentation and microbial protein synthesis in sheep. J. Agric. Sci., 124:463-472.

STREETER, M.N., MATHIS, M.J. 1995. Effect of suplemental meal fish protein on site and extent of digestion in beef steers. J. Anim. Sci., 73(4):1196-1201

VAN SOEST, P.J. 1994. Nutritional ecology of the ruminant. 2.ed. London: Cornell University. 476p.

VILELA, E.R., FERREIRA, M.E. 1987. Tecnologia de produção e utilização do amido de mandioca. Inf. Agropec., 13(145):69-73.

WALDO, D.R. 1973. Extent and partition of cereal grain starch digestion in ruminants. J. Anim. Sci., 37(4):1061-1073.

ZEOULA, L.M., MARTINS, A.S., ALCALDE, C.R. et al. Solubilidade e degradabilidade ruminal do amido de diferentes alimentos. 1999. Rev. bras. zootec., 28(5):905-912.

ZEOULA, L. M., PRADO, I.N., BRANCO, A.F. et al. 1998 Valor nutritivo de rações compostas de fontes de amido e de nitrogênio com alta e baixa degradabilidade ruminal. R. Bras. Zootec., 28(5):1159-1167.

Recebido em: 27/06/00

Aceito em: 02/01/01 